\title{
PEMANFAATAN BAGAS SEBAGAI MEDIA UNTUK PERTUMBUHAN DAN PRODUKSI JAMUR TIRAM PUTIH (Pleurotus ostreatus)
}

\author{
Elsie, Juliana, Wirdati Irma.
}

\author{
Staf Pengajar Program Studi Biologi, Fakultas MIPA dan Kesehatan, \\ Universitas Muhammadiyah Riau (UMRI), \\ Mahasiswa Program Studi Biologi, Fakultas MIPA dan Kesehatan, UMRI
}

\begin{abstract}
ABSTRAK
Jamur tiram secara alami tumbuh pada batang-batang kayu yang telah mengalami pelapukan. Jamur tiram dapat tumbuh pada media serbuk kayu, jerami padi, alang-alang, sisa kertas, ampas tebu, kulit kacang, dan bahan media lainnnya. Penelitian dilaksanakan secara eksperimen menggunakan Rancangan Acak Lengkap (RAL), yang disusun secara faktorial yang terdiri dari satu faktor dengan 5 perlakuan dan 3 ulangan yaitu $\mathrm{P}_{0}$ : konsentrasi serbuk kayu $100 \%$ dan bagas $0 \%$ (kontrol), $\mathrm{P}_{1}$ : konsentrasi serbuk kayu $75 \%$ dan bagas $25 \%, \mathrm{P}_{2}$ : konsentrasi serbuk kayu $50 \%$ dan bagas $50 \%, \mathrm{P}_{3}$ : konsentrasi serbuk kayu $25 \%$ dan bagas $75 \%$, dan $\mathrm{P}_{4}$ : konsentrasi bagas $100 \%$. Untuk menganalisis pertumbuhan jamur tiram putih, digunakananalisis varian (Anova) taraf 5\% yang dilanjutkan dengan uji Beda Nyata Terkecil (BNT) taraf $5 \%$. Hasil penelitian menunjukkan rata-rata jumlah tubuh buah berturut-turut yaitu $\mathrm{P}_{0} 5,33$ buah, $\mathrm{P}_{1} 8,00$ buah, $\mathrm{P}_{2} 8,33$ buah, $\mathrm{P}_{3} 10,33$ buah dan $\mathrm{P}_{4} 18,00$ buah. Jumlah tubuh buah tertinggi diperoleh pada perlakuan $\mathrm{P}_{4}$ yaitu 18,00 . Sedangkan rata-rata berat basah jamur berturut-turut yaitu $\mathrm{P}_{0} 33,33 \mathrm{gr}, \mathrm{P}_{1}$ 66,67gr, $\mathrm{P}_{2} 66,67 \mathrm{gr}, \mathrm{P}_{3}$ 80,00gr dan $\mathrm{P}_{4}$ 96,67gr. Berat basah jamur tertinggi diperoleh pada perlakuan $\mathrm{P}_{4}$ yaitu 96,67gr. Dapat disimpulkan bahwa pemberian bagas sebagai media pertumbuhan jamur tiram putih dapat meningkatkan jumlah tubuh buah dan berat basah jamur tiram putih.
\end{abstract}

Kata kunci: Bagas, Jamur Tiram Putih, Serbuk Kayu.

\section{PENDAHULUAN}

Indonesia khususnya Propinsi Riau merupakan daerah tropis yang memiliki kekayaan hutan yang cukup melimpah sehingga terdapat industri-industri yang menghasilkan limbah kayu khususnya pada penggergajian kayu. Menurut Badan Pusat Statistik Pekanbaru (2011), produksi total kayu gergajian di Propinsi Riau pada tahun 2009 mencapai $10.303,14 \mathrm{~m}^{3}$ dan $15 \%$ dari produksi tersebut berupa serbuk gergajian.Menurut Khairatet al (2009), serbuk gergaji dapat dimanfaatkan sebagai bahan baku pembuatan sodium lignosulfonat dan aplikasinya untuk meningkatkan kekuatan beton mortar. Namun tidak semua serbuk gergaji yang ada telah dimanfaatkan, sehingga bila tidak ditangani dengan baik maka dapat menjadi masalah lingkungan yang serius.Untuk mengurangi tingkat pencemaran yang tinggi, serbuk kayu dapat dimanfaatkan agar mempunyai nilai ekonomis, yakni menjadikannya sebagai media tanam bagi pertumbuhan jamur. Serbuk kayu yang digunakan sebagai tempat tumbuh jamur mengandung serat organik (serat dan lignin). Kandungan tersebut dapat mempercepat pertumbuhan jamur.

Jamur tiram merupakan jenis jamur kayu yang secara alami tumbuh pada batang-batang kayu yang telah mengalami pelapukan dan umum dijumpai di daerah hutan-hutan. Jamur tiram saat ini dibudidayakan secara besar-besaran dengan menggunakan berbagai media tanam. Jamur tiram dapat tumbuh pada media serbuk kayu, jerami padi, alang-alang, sisa kertas, ampas tebu, kulit kacang dan bahan media lainnnya (Hardi, 2000). Banyaknya pilihan media yang dapat digunakan menuntut untuk dapat memilih bahan media yang paling efisien, mudah didapat, harganya murah (ekonomis) dan pertumbuhan jamurnya lebih cepat.

Jamur merupakan golongan tumbuhtumbuhan yang tubuhnya tidak mempunyai diferensiasi, sehingga disebut tumbuhan talus (thallophyta) yang tidak mempunyai klorofil (Dwidjoseputro, 2005). Jamur hidup dengan cara mengambil zat-zat makanan seperti selulosa, 
glukosa, lignin, protein dan senyawa pati dari organisme lain. Di alam, zat-zat nutrisi tersebut biasanya telah tersedia dari proses pelapukan oleh aktivitas mikroorganisme (Djarijah \& Djarijah, 2001).

Untuk perkembangannya, jamur tiram memerlukan sumber nutrien atau makanan dalam bentuk unsur-unsur kimia, misalnya nitrogen, vitamin, mineral, fosfor, belerang, kalsium dan karbon (Djarijah dan Djarijah, 2001).

Dalam penelitian ini digunakan serbuk kayu dan ampas tebu (bagas) sebagai media pertumbuhan jamur. Serbuk kayu digunakan karena selain mempunyai kandungan serat, juga dapat mengurangi pencemaran. Bagas juga dapat digunakan sebagai media pertumbuhan jamur karena mengandung selulosa, lignin serta dapat mengurangi pencemaran. Dari hasil survei yang dilakukan, di Pekanbaru banyak ditemukan bagas sebagai limbah dari penjual air tebu.

Tujuan penelitian ini adalah untuk mengetahui konsentrasi bagas dan serbuk kayu yang efektif terhadap pertumbuhan tubuh buah dan berat basah jamur tiram putih (Pleurotus ostreatus).

\section{METODOLOGI PENELITIAN}

Penelitian ini dilaksanakan pada bulan JuliAgustus 2012bertempatdi Permata Jamur Kulim Pekanbaru Riau.Penelitian ini termasuk penelitian eksperimen dengan menggunakan pola Rancangan Acak Lengkap (RAL) yang disusun secara faktorial terdiri dari satu faktor dengan 5 taraf perlakuan dan 3 kali ulangan sebagai berikut:

P0: Konsentrasi serbuk kayu $100 \%$ dengan bagas $0 \%$ (kontrol)

P1: Konsentrasi serbuk kayu $75 \%$ dengan bagas $25 \%$

P2: Konsentrasi serbuk kayu 50\% dengan bagas $50 \%$

P3: Konsentrasi serbuk kayu 25\% dengan bagas $75 \%$

P4: Konsentrasi bagas 100\%

Alat yang digunakan dalam budidaya jamur tiram adalah ayakan, sekop, timbangan, plastik polipropilen, potongan paralon, karet, baskom, ember, lampu bunsen, drum (steam), kamera dan rumah jamur, sedangkan bahan yang digunakan adalah bibit jamur tiram putih, alkohol, serbuk kayu, bekatul, kapur $\left(\mathrm{CaCO}_{3}\right)$, gips $\left(\mathrm{CaCO}_{4}\right)$, bagas dan air.

\section{A. Pelaksanaan kegiatan}

Menyiapkan alat dan bahan yang digunakan. Media tanam yang digunakan pada masingmasing perlakuan adalah:

P0: 300 gram serbuk kayu, 100 gram bekatul, 20 gram kapur, 10 gram gips, dan air.

P1: 225 gram serbuk kayu, 100 gram bekatul, 20 gram kapur, 10 gram gips, 75 gram bagas, dan air.

P2: 150 gram serbuk kayu, 100 gram bekatul, 20 gram kapur, 10 gram gips, 150 gram bagas, dan air.

P3: 75 gram serbuk kayu, 100 gram bekatul, 20 gram kapur, 10 gram gips, 225 gram bagas, dan air.

P4: 100 gram bekatul, 20 gram kapur, 10 gram gips, 300 gram bagas, dan air.

\section{B.Tahap Pelaksanaan}

Pembuatan media tanam adalah sebagai berikut:

1. Serbuk kayu diayak terlebih dahulu agar terpisah dari potongan potongan yangkasar, kemudian ditimbang sebanyak 300 gram.

2. Bahan-bahan (bekatul, gips, kapur) dicampurkan ke dalam serbuk kayu kemudian ditambahkan air dan diaduk sampai rata. Bagas kering ditambahkan sesuai dengan perlakuan (lihat Tabel 3.1).

3. Media tanam dimasukkan ke dalam plastik polipropilen, kemudian dipadatkan.Masingmasing perlakuan diulang sebanyak 3 kali.

4. Media tanam disterilisasi dalam drum (steam) selama 8 jam pada suhu $90-100^{\circ} \mathrm{C}$.

5. Bibit jamur diinokulasikan ke dalam media tanam dengan cara ditebarkan di atas media tanam kemudian diberi potongan paralon dan koran selanjutnya diikat menggunakan karet gelang.

6. Bibit diinkubasi sampai misellium memenuhi media tanam. Setelah misellium memenuhi media tanam, media tersebut siap dipindahkan ke rumahjamur dengan cara direbahkan di atas 
rak, kemudian media tanam disayat dengan bentuk persegi agar jamur dapat tumbuh dengan baik. Setelah hifa-hifa mengalami tahapan plasmogami, kariogami, dan meiosis hingga membentuk bakal jamur, maka jamur dapat langsung dipanen.

\section{Analisis Data}

Untuk menganalisispertumbuhan jamur tiram putih, dipergunakan analisis varian (Anova) taraf 5\%. Setelah dilaksanakan analisis data Anova, maka dilanjutkan dengan uji Beda Nyata Terkecil (BNT) taraf 5\%.

\section{Parameter yang diamati}

Parameter yang diamati adalah sebagai berikut:

A. Jumlah tubuh buah jamur

Tabel 1. Jumlah Tubuh Buah Jamur Tiram Putih

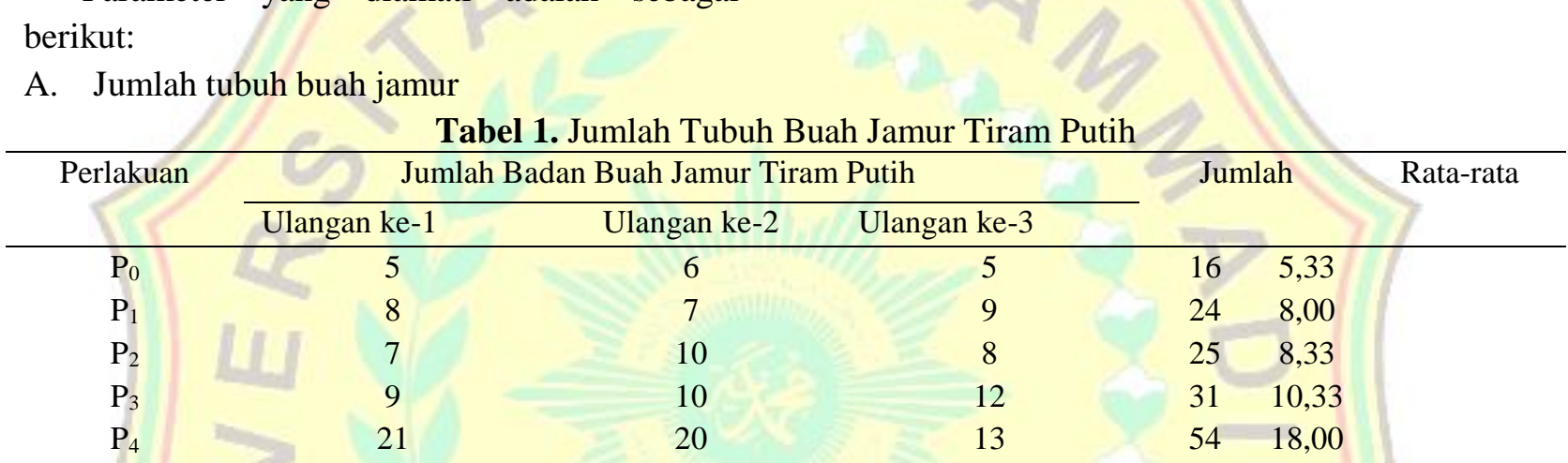

Hasil jumlah tubuh buah jamur tiram putih yang diperoleh pada Tabel 1 terjadi peningkatan antar perlakuan. Pada perlakuan $\mathrm{P}_{0}$ (media tanam $100 \%$ serbuk kayu dan $0 \%$ bagas) diperoleh nilai rata-rata 5,33 buah. Pada perlakuan $\mathrm{P}_{1}$ (media tanam $75 \%$ serbuk kayu dan $25 \%$ bagas) dan $\mathrm{P}_{2}$ (media tanam $50 \%$ serbuk kayu dan $50 \%$ bagas) terjadi peningkatan jumlah tubuh buah jamur bila dibandingkan dengan perlakuan $\mathrm{P}_{0}$ dengan nilai rata-rata 8,00 dan 8,33 buah. Pada perlakuan $\mathrm{P}_{3}$ (media tanam $25 \%$ serbuk kayu dan $75 \%$ bagas) juga terjadi peningkatan jumlah tubuh buah jamur bila dibandingkan dengan $\mathrm{P}_{0}$ dengan nilai rata-rata 10,33 buah. Jumlah tubuh buah jamur tiram yang paling nyata perbedaannya terjadi pada perlakuan $\mathrm{P}_{4}$ (media tanam $100 \%$ bagas) yang memiliki nilai rata-rata 18,00 . Dari hasil perhitungan diperoleh $\mathrm{F}$ hitung $>\mathrm{F}$ Tabel yaitu 13,9> 3,48. Artinya pemberian bagas sebagai mediapertumbuhan jamur tiram dapat meningkatkan jumlah tubuh buah jamur.
Pengamatan dilakukan dengan

menghitung jumlah tubuh buah jamur masing-masing perlakuan pada panen pertama.

B. Berat basah jamur tiram putih

Pengamatan dilakukan dengan menimbang berat basah jamur tiram pada panen pertama.

\section{HASIL DAN PEMBAHASAN}

\section{Jumlah Tubuh Buah Jamur Tiram Putih}

Setelah bibit jamur tiram putih diinokulasi di atas media pertumbuhan dan diinkubasi selama \pm 40 hari, diperoleh hasil jumlah tubuh buah jamur tiram putih pada setiap perlakuan yang disajikan pada Tabel 1. berikut ini. perlakuan yang menghasilkan jumlah tubuh buah yang paling banyak adalah pada perlakuan $\mathrm{P}_{4}$ dengan nilai 12,67. Artinya pemberian bagas pada media pertumbuhan jamur tiram putih dapat meningkatkan jumlah tubuh buah jamur tiram tersebut. Terjadinya peningkatan jumlah tubuh buah jamur kemungkinan disebabkan oleh media bagas. Bagas mengandung lignin sekitar 24,2\%, selulosa $52,7 \%$ dan hemiselulosa $17,5 \%$ (Samsuri, et al, 2007).

Kandungan yang terdapat pada bagas tersebut sangat dibutuhkan untuk pertumbuhan jamur, karena jamur hidup dengan cara menyerap atau mengambil zat-zat makanan dari organisme lain. Penelitian sebelumnya yang dilakukan oleh Dewi (2004), diperoleh jumlah tubuh buah pada perlakuan $\mathrm{B}_{4}$ (media tanam $1 \mathrm{~kg}$ serbuk kayu dengan penambahan $0,04 \mathrm{~kg}$ blotong) dengan nilai rata-rata 10,333 buah. 
data berat basah jamur tiram dapat dilihat pada Tabel 2 berikut

Tabel 2. Berat Basah (gram) Jamur Tiram Putih

\begin{tabular}{cccccc}
\hline \multirow{2}{*}{ Perlakuan } & \multicolumn{3}{c}{ Berat Basah Jamur Tiram Putih } & Jumlah & Rata-rata \\
\cline { 2 - 4 } & Ulangan ke-1 & Ulangan ke-2 & Ulangan ke-3 & & \\
\hline $\mathrm{P}_{0}$ & 30 & 30 & 40 & 100 & 33,33 \\
$\mathrm{P}_{1}$ & 70 & 60 & 70 & 200 & 66,67 \\
$\mathrm{P}_{2}$ & 60 & 70 & 70 & 200 & 66,67 \\
$\mathrm{P}_{3}$ & 70 & 80 & 90 & 240 & 80,00 \\
$\mathrm{P}_{4}$ & 110 & 100 & 80 & 290 & 96,67 \\
\hline
\end{tabular}

Data berat basah jamur tiram putih (Tabel 2) terjadi peningkatan pada setiap perlakuan. Berat basah jamur rata-rata setiap perlakuan adalah $\mathrm{P}_{0}$ $33,33 \mathrm{gr}, \mathrm{P}_{1} 66,67 \mathrm{gr}, \mathrm{P}_{2} 66,67 \mathrm{gr}, \mathrm{P}_{3} 80,00$ gr dan $\mathrm{P}_{4} 96,67$ gr. Perlakuan $\mathrm{P}_{0}$ (media tanam tanpa bagas), didapat hasil yang lebih rendah dibandingkan dengan perlakuan yang lain yaitu rata-rata 33,33gr. Pada perlakuan $\mathrm{P}_{1}$ (media tanam $25 \%$ bagas) dan $\mathrm{P}_{2}$ (media tanam $50 \%$ bagas), menunjukkan hasil yang lebih baik dibandingkan dengan perlakuan $\mathrm{P}_{0}$ (media tanam tanpa bagas) dengan nilai rata-rata $66,67 \mathrm{gr}$. Sedangkan pada perlakuan $\mathrm{P}_{3}$ (media tanam bagas $75 \%$ ) diperoleh hasil rata-rata 80,00 gr. Pertambahan berat basah jamur tiram putih paling tinggi terdapat pada perlakuan $\mathrm{P}_{4}$ (media tanam bagas $100 \%$ ) dengan nilai rata-rata sebesar 96,67gr. Hasil perhitungan diperoleh $\mathrm{F}$ hitung > F Tabel yaitu 18,77> 3,48. Artinya pemberian bagas sebagai media pertumbuhan jamur dapat meningkatkan berat basah jamur tiram putih. Hasil uji BNT juga menunjukkan bahwa perlakuan yang menghasilkan berat basah jamur tertinggi adalah perlakuan $\mathrm{P}_{4}$ (bagas 100\%) dengan nilai 63,34. Jadi perlakuan $\mathrm{P}_{4}$ merupakan perlakuan yang paling efektif untuk meningkatkan berat basah jamur. tiram. Semakin banyak tubuh buah jamur yang dihasilkan per baglog, maka akan meningkatkan nilai produksi karena berat basah jamur tersebut juga meningkat. Terjadinya peningkatan berat basah jamur tersebut kemungkinan disebabkan oleh bagas. Pemberian bagas $100 \%$ sebagai media tanam jamur banyak mengandung unsur hara seperti selulosa, lignin, dan kadar air (Andaka, 2011)

\section{KESIMPULAN}

Hasil penelitian menunjukkan bahwa kelima taraf perlakuan diperoleh hasil jumlah tubuh buah jamur berturut-turut yaitu $\mathrm{P}_{0}$ (media tanam $100 \%$ serbuk kayu dan $0 \%$ bagas) 5,33 buah, $\mathrm{P}_{1}$ (media tanam $75 \%$ serbuk kayu dan $25 \%$ bagas) 8,00 buah, $\mathrm{P}_{2}$ (media tanam $50 \%$ serbuk kayu dan $50 \%$ bagas) 8,33 buah, $\mathrm{P}_{3}$ (media tanam $25 \%$ serbuk kayu dan $75 \%$ bagas) 10,33 buah dan $\mathrm{P}_{4}$ (media tanam $100 \%$ bagas) 18,00 buah. Dari lima taraf perlakuan tersebut diperoleh hasil berat basahjamur tiram dengan nilai ratarata yaitu $\mathrm{P}_{0} 33,33 \mathrm{gr}, \mathrm{P}_{1} 66,67 \mathrm{gr}, \mathrm{P}_{2}$

Berdasarkan hasil penelitian, disarankan bagi petani jamur untuk memanfaatkan bagas sebagai media pertumbuhan jamur tiram putih, karena dapat meningkatkan nilai produksi. Dan diharapkan adanya penelitian lanjutan untuk mengetahui optimalisasi waktu panen dengan menggunakan media bagas dan serbuk kayu.

\section{DAFTAR PUSTAKA}

Aminah, N.S., Achmad, S.A., Hakim, E.H., Syah, Y.M., Juliawaty, L.D., dan Ghisalberti, E.L. (2003). Laevifonol, Diptoindonesin A, dan Ampelopsin A, Tiga Dimer Stilbenoid dari Kulit Batang Shorea seminis V. Sl. (Dipterocarpaceae). Jurnal Matematika dan Sains. 8 (1). 31-34

Andaka, Ganjar. 2011. Hidrolisis Ampas Tebu menjadi Furfural dengan Katalisator Asam Sulfat. Jurnal Teknologi 4 (2). Hlm 180188.

BPS. 2011.Produksi Total Kayu Olahan Menurut Jenis.Riau dalam Angka. Badan Pusat Statistik Pekanbaru. 
Chazali, S dan P.S.Pratiwi. 2010. Usaha Jamur Tiram. Jakarta: Penebar Swadaya.

Dewi, I. K. 2009. "Efektivitas Pemberian Blotong Kering Terhadap Pertumbuhan Jamur Tiram Putih (Pleurotus Ostreatus) Pada Media Serbuk Kayu" [Skrisi]. Program Pendidikan FKIP Biologi. Universitas Muhammadiyah Surakarta.

Djarijah, N. M dan A. S. Djarijah. 2001. Budidaya Jamur Tiram. Jakarta: Kanisius.

Dwijdoseputro. $2005 . \quad$ Dasar-Dasar Mikrobiologi. Jakarta: Djambatan.

Gunawan, A.W. 2000. Usaha Pembibitan Jamur. Jakarta: Penebar Swadaya

Hardi, Soenanto. 2000. Budidaya dan Peluang Usaha Jamur Tiram. Semarang: CV Aneka Ilmu, IKAPI.

Hendritomo, H. I. 2010. Jamur Konsumsi Berkhasiat Obat. Yogyakarta: Lily Publisher.

Khairat., Yelmida dan A. Amri. 2009. Studi Pemanfaatan Serbuk Gergaji Sebagai Bahan Baku Pembuatan Sodium Lignosulfonat dan Aplikasinya Untuk meningkatkan Kekuatan Beton Mortar. Jurnal Sain dan Teknologi 8(2). Hlm 45-49.

Malau, K, M. 2009. "Pemanfaatan Ampas Tebu Sebagai Bahan Baku Dalam Pembuatan Papan Partikel" [Skripsi]. Universitas Sumatera Utara: Medan.

Nurmiyati 2007. "Implementasi Hasil Penelitian Biologi Pada Siklus Pertumbuhan Jamur Sebagai Sumber Belajar Materi Fungi Sma Kelas X Semester Ganjil Kurikulum Ktsp"
[Skripsi]. Universitas Sebelas Maret: Surakarta.

Pasaribu, T., R.P. Djumhawandan R.A. Eisrin. 2002. Aneka Jamur Unggulan. Jakarta: PT Grasindo.

Rati, R dan Sumarsih, S. 2002. "Pengaruh Perbandingan Bagas dan Blotong Terhadap Pertumbuhan dan Produksi Jamur Tiram Putih". [Skripsi]. UPN: Yogyakarta.

Samsuri., M. Gozan., R. Mardius., M. Baiquni., H. Hermansyah., A. Wijanarko., B. Prasetya dan Nasikin. 2007. Pemanfaatan Selulosa Bagas untuk Produksi Ethanol Melalui Sakarifikasi dan Fermentasi Serentak dengan Enzim Xylanase. Jurnal Makara Teknologi. 11(1). Hlm 17-24.

Sumarmi. 2006. Botani dan Tinjauan Gizi Jamur Tiram Putih. Jurnal Inovasi Pertanian4(2). Hlm 124-130.

Suriawiria, Unus. 2001. Sukses Beragrobisnis Jamur Kayu. Jakarta.. 2002. Budidaya Jamur Tiram. Yogyakarta: Kanisius.

Tjitrosoepomo, G. 2010. Taksonomi Tumbuham Obat-Obatan. Yogyakarta: Gadjah Mada University Press.

Wiardani, I. 2010. Budidaya jamur Konsumsi. Yogyakarta: Lili publisher.

Winarni,I dan U. Rahayu. 2002. Pengaruh Formulasi Media Tanam dengan Bahan Dasar Serbuk Gergaji terhadap Produksi Jamur Tiram Putih (Peurotus ostreatus).Jurnal Matematika, Sain dan Teknologi. 3(2). Hlm 20-27. 